\title{
RE-THINKING NATIONAL LANGUAGE AND NATIONAL DEVELOPMENT IN A MULTI-ETHNIC NIGERIA: QUOD VADIS PRO ME?
}

\section{Uche Oboko (Ph.D.) ${ }^{1}$ and Remi Chukwudi Okeke (Ph.D.) ${ }^{2}$}

${ }^{1}$ Department of English, Madonna University, Nigeria. Email: ucheoboko@yahoo.com

${ }^{2}$ Department of Public Administration, Madonna University, Okija Campus, Anambra State, Nigeria. Email: remiokeke@gmail.com

Cite this article:

Oboko U., Okeke R.C. (2021), Re-Thinking National Language and National Development in a MultiEthnic Nigeria: Quod Vadis Pro Me?. African Journal of Social Sciences and

Humanities Research 4(4), 110. DOI: 10.52589/AJSSHRSAWRPEG4.

\section{Manuscript History}

Received: 12 June 2021

Accepted: 9 July 2021

Published: 26 July 2021

Copyright $(\odot 2020$ The Author(s). This is an Open Access article distributed under the terms of Creative Commons AttributionNonCommercial-NoDerivatives 4.0 International (CC BY-NC-ND

4.0 ), which permits anyone to share, use, reproduce and redistribute in any medium, provided the original author and source are credited.
ABSTRACT: The issue of national language and national development has been at the forefront of language issues in nation-states. The persistent demand for a national language seems to stand from the point of view that it will engender national development. The present study critically examines the case of Nigeria from the historical perspective, the case of a single national language and its role in national development, or otherwise, in a densely multi-linguistic and pluralistic Nigeria. Finally, the paper makes an attempt at formulating an appropriate and comprehensive choice of language policy that recognizes the language of the people across geographical boundaries and the exogenous language in order to foster generic development, national cohesion and accelerated national development.

KEYWORDS: National language, National language policy, National development, Multi-linguistic nationalities, Pluralistic Nations 


\section{INTRODUCTION}

Language is an indispensable tool in the life of every individual. It pervades every aspect of man's life. Man uses language to express himself, exchange ideas, dress his thoughts, invent things and develop his environment. Language does not only help man to actualize himself. It controls man and his actions. This is why it is believed that the language we use mirrors how we think, perceive and assess situations. Akamjian et al. (2001, p. 9) present the point clearer when they comment that language is a mirror of the mind in a deep and significant sense and also a product of human intelligence. In addition, language does not exist in a vacuum. It is the product of society. Every society creates its language and uses it to achieve its function. This shows that language is always contextualized because it is situated within a particular socio-cultural setting. The use of language, therefore, reflects the culture of every society. Fromkin et al. (2011, p. 284) capture the essence of language in human existence when they express that 'the possession of language perhaps more than any other attribute distinguishes humans from other animals. According to them, to understand our humanity, one must understand the nature of language that makes us human. Language is, therefore, the prerogative of man and a distinguishable attribute of humans. Our humanity is threatened whenever anything happens to our language.

\section{THEORETICAL UNDERPINNING}

\section{Language and National Development: A Nexus}

The indispensability of language in the development of any society is made clearer in the story in Genesis11: 1-9 where the people were united in a common front in building a tower because they had a common language but could not forge ahead when God used different languages to thwart their efforts. Francis (1969) observes that it is natural to be suspicious of those who speak differently from us and be more at home with those who speak the same language as us (cited in Ike 1998). In line with this, scholars have argued that a nation will be more developed if it evolves a common language of communication. It is believed that a common language, (call it a national language as defined by Elugbe (1995) or a lingua franca) will not only facilitate unison in matters affecting the citizens but will reduce suspicion, distrust, misgivings and doubts among the citizens and engender national development. Oneness of language will help to unite the different linguistic, ethnic, religious blocks in a nation like Nigeria and make formulation and implementation of government policies possible as the groups will be able to cooperate and communicate towards achieving a common goal. On the benefit of single language use in African nations, Ndolo citing Smock (1974) espouses:

Ultimately and ideally, the countries of West Africa would succeed faster and more effectively in bringing about national unity and the other benefits of homogenous nationhood if steps are taken now to promote a single language as a medium of communication in the country $(1989$, p. 679).

Since a national community is inconceivable without a common language (Stalin 1976, p. 20), it follows that no nation can witness development without recourse to a medium of communication clearly defined and accepted by the members of the linguistic community. Okoh (2002) points out the importance of language to man when he avers that man can hardly 
do, let alone achieve anything without embracing the tool of language (cited in Okoh, 2006, p. 9).

Conversely, language can impede national development in a situation where it breeds ethnic sentiments, prejudices, biases, suspicion, tribalism, favouritism and ethnocentrism. The development, unity and oneness of the nation may be affected when people speak different 'tongues'. Ofoegbu $(2017$, p. 41$)$ summarizes the point in his argument that any country without a common language or a national language, lacks political, economic, social, cultural cohesion to identify and set common collective or national goals and objectives which form the bedrock of national development. In Nigeria, evolving a single national language has remained clearly a vexed, political issue than a linguistic concern as in most African nations.

Inasmuch as a national language is important for oneness and national integration, evolving a single national language is not the only avenue through which development can be assured in a nation. The present paper holds that apart from a single language option, a country may decide to seek alternative choices to develop common languages in situations where it has become increasingly difficult to evolve a single language option as in Nigeria. Developing a single language philosophy in Nigeria is not the only way to demonstrate our patriotism, Nigerianness or uniqueness. Development can also be achieved in a multilingual nation like Nigeria when the citizens agree to particular language choices that involve a greater population of the nation either at the national or other levels but paying attention to what is indigenous to the nation. Since several efforts made at evolving a national language have remained elusive, Nigerians, therefore, should seek more feasible options of language policy instead of dissipating energy on unworkable options which have been on for several years. In line with this, Okoh (2006) strongly advises that instead of dwelling on a single language choice, Nigerians should rather redirect energies to more tenable and workable language options in order to solve the language problem in Nigeria.

Taking a cue from the regional security issues in Nigeria, where the different geographical zones have decided to adopt their own security arrangement to support the central security operations, the present paper holds that alternative and workable language options should be sought along geographical levels to support the central adopted lingua franca (English).

\section{Previous Scholarly Attempts at National Language Options and Problem Identification}

Evolving a national language position and the implementation of a national language policy have been problems in Nigeria due to the multi-ethnolinguistic nature of the country. Different scholars have made various attempts at finding solutions to this situation but the problem appears to have persisted. For instance, Oyetade (2003) examined language policy and planning attempts in Nigeria since independence against the backdrop of language planning in a country like Canada with similar linguistic problems as Nigeria. He advocates a strategy of governance that allows for greater decentralization of power and which recognizes and protects the linguistic rights of all Nigerians. More so, Nwobia (2015) appraises the role of language in national development. The paper takes for granted that English provides access to global markets and science and technology but solicits that the indigenous language should be empowered to meet up with the technological drive of the 21st Century. Similarly, Jowitt (1995) in looking at Nigeria's national question reviewed some of the options given by scholars and the role that English is expected to play. 
In addition, other scholars have recommended other options like the adoption of any of the major three languages; option of a minority language - Igala, the choice of an artificial language- Swahili, the choice of Pidgin, the option of Afrike, the option of combining the three languages-(WAZOBIA), a coined language option- GUOSA, among others. Although each of these options has its assumed benefits, it equally has its associated problems. All the extant studies provide insight into the current study. However, the current study seeks a different approach by looking at the last population census in Nigeria, the popularity of languages in the different zones and suggesting common language options in Nigeria along the geopolitical/geographical zones.

\section{REVIEW OF LITERATURE}

\section{Archival Consideration of Language History in Nigeria}

Evolving a single language to serve as a national language has been a herculean task in Nigeria due to the pluralistic nature of the country. The multi-linguistic nature dates back to history. Before the advent of the colonial masters, what is today known as Nigeria, existed as multiple ethnic groups. Each of the ethnic groups had its own distinct structure in terms of language use, cultural patterns, administrative system, which is expressed in their religious, educational, traditional and socio-political system. In the Northern area, languages like, Hausa, Fulani, Kanuri, Tiv, Nupe and others were in use. In the Southern sections, languages like Yoruba, Igbo, Edo, Efik, Urhobo, Ijaw, Ibibio and others were used. Ogunmodimu (2015, p.155) citing Ajayi (1967) posits that there was really no completely isolated tribe, but that the different ethnic groups were in constant touch with one another through economic activities and military expansionism. The contact and business exchanges led to linguistic and cultural exchanges. The contact equally brought in some lexical borrowings from the two groups. Apart from this, the coming of the missionaries and slave merchants brought in another language contact between the indigenous people and the foreigners who came through the coastal regions of Lagos and Calabar. Ogunmodimu (2015 p. 155) citing Huber (1999) further asserts that after the slave trade was abolished in 1807, some of the slaves who had acquired western education came back to serve as interpreters and copyists to the missionaries. Among them was the popular Ajayi Crowder who translated the English Bible into Yoruba.

Again, during the colonial era, the missionaries established schools. The English language became the medium of instruction and the language of administration, their gospel was also propagated using the English language. The language became the elitist language and more people clamoured to learn the language as it is seen as the vehicle for economic improvement. White-collar jobs were offered to people who could speak or write the English language. In spite of the enticement, the language was not accepted easily in the North, the way it was accepted in the southern part of the territory. The People of Northern Nigeria held their Arabic language and Islamic religion firmly and only a few of them accepted Christianity. Despite the difference between what became known as the Northern and Southern protectorates under colonialism, in the acceptance of the English language, religious and cultural differences, the British officers amalgamated the two protectorates in 1914.

In 1960, the nation gained independence. The country was divided into three regions: Northern, Western and Eastern by the colonizers. Even after the independence and exit of the colonial 
masters, the English language continued to flourish. The language has continued to serve as the official language in the midst of over five hundred and twenty-one ethnic languages operational in the nation. English was given a prominent position alongside the three major languages: Hausa, Igbo and Yoruba. Other minor languages such as Ijaw, Ibibio, Urhobo, Igala, Esan, Ebira, Fulfude Kanuri, Efik, Gwari, and others are considered minority languages: The chosen languages equally perform major linguistic functions in the speech communities where they are used. The language types identified in Nigeria is presented in this table.

\section{Table 1: Language Types in Nigeria}

1. Exogenous English, French, Arabic

2. Indigenous

Over 521

3. Neutral

\section{National Development}

National development can be seen as a situation whereby a nation seeks to improve the condition of the citizenry through human capital and infrastructural development. This suggests that such a nation should be able to develop the human capital and infrastructures through the provision of basic social amenities like quality education, medical care, security to mention a few. National Development is all about developing the wellbeing of the people and involves giving a defined meaning to the lives of the citizenry. Hence, Olaoye (2013, p. 30) sees national development as a situation whereby people harness the resources at their disposal in order to have meaningful lives. This development notion ranges from growth in education (intellectual growth), politics, economy, science and technology. In the educational process, language is the main pillar through which man has to plan, instruct and evaluate programmes. Developing a language structure through which the majority of the citizenry is educated engenders development. The development of individuals in respect of their aspirations in society means the development of a nation.

In other words, individuals in the nation develop educationally, socially, economically, politically, and otherwise. Against this backdrop, Aziza (1998) sees national development as a gradual and advanced improvement or growth through progressive changes in the sociopolitical life of the nation. Corroborating the position, Elugbe (2006) maintains that national development refers to the growth of the nation in terms of internal cohesion, integration, unity, economic wellbeing, mass participation in government and educational growth. By implication, development in a nation implies that all sectors of the nation should witness development. In sum, a developed nation understands the reason for its existence. They have a common way of doing things. The common way of doing things include the use of a common language that most citizens can communicate effectively and fluently in order to foster national development. Depending on the option, a common language may be adopted along a national line or geographical boundaries. The current paper proposes the adoption of common languages along geopolitical boundaries for national development. 


\section{DISCUSSION}

\section{National Language and National Development in Nigeria: A Simple Proposal}

Nigeria is a vast country in terms of ethnic, geographical, cultural, linguistic and religious boundaries. The pluralistic linguistic nature of the nation has been a major impediment in choosing a national language. Some nations have been able to adopt a national language for their use and operations. Such nations include Great Britain where English is used, Tanzania and Kenya where Swahili is used and the Philippines where Filipino serves as the national language. Other nations like Indonesia adopted Bahasa Indonesia as their national language, Papua New Guinea uses Tokpisin and Hong Kong uses Chinese as their official language. These countries and many others have been able to achieve a national language because they have a common tradition. Achieving such a feat in Nigeria is mountainous. Since it has been difficult choosing a national language and equally more threatening to adopt any of the three major indigenous languages, the present paper proposes the adoption of a common language along the geographical divides and also retaining the English language as the lingua Franca.

During the Sani Abacha regime in 1995, Nigeria was divided into six geographical or geopolitical zones, with Nigerian federating states joined by proximity and cultural affiliations in each of the zones. It is easier to adopt a popular language among the languages in the geographical region as a common language. In considering the option of a geographical language, the population of the speakers and other factors play key roles. Ndukwe (2015, p.78) advocates that in considering the choice of a common language for a group of people factors such as the population of speakers, acceptability, vertical integration, language development and status play major roles. According to her, population is an important factor in choosing a common language for a group of people as shown from sociolinguistic researches and the rate of success recorded in other nations. In line with the assertion, the population of speakers and the dominance of a language in a particular zone formed the major yardstick for the decision on the choices.

Besides, looking at the languages, one will agree with Okoh (2006, p. 247) that in spite of the emphasis on the British origins of Nigeria, and the commonly presumed absolute differences between the people, there are remarkable, 'intriguingly enormous similarities' between the diverse cultures. Judging from the figures drawn from the last national population census in 2006, of about 140,431,790 million Nigerians, 29\% speak Hausa/ Fulani, 21\% speak Yoruba, while $18 \%$ speak Igbo. In addition, $10 \%$ of the population speak Ijaw, $3.5 \%$ speak Ibibio, 2.5\% speak Tiv, 3.5\% speak Ibibio/ Efik, 4\% speak Kanuri, less than 1\% speak Edo language and less than $1 \%$ speak Nupe (minority rights. org/country/ Nigeria). From the available statistics and based on the population of speakers, it is observed that $78 \%$ of the population speak, Hausa, Yoruba, Igbo and Ijaw while about $22 \%$ speak other languages. Five out of the six states with high population in the Northeast zone: Bornu, Gombe, Adamawa, Yobe and Bauchi with the exception of Taraba speak Hausa which is the dominant language followed by Kanuri and Fulani.

In the Northwest zone, in addition to the minor languages, all the seven states in the zone: Kano, Jigawa, Sokoto, Katsina, Zamfara, Kaduna and Kebbi speak Hausa. Looking at the languages spoken in the various zones, it appears that the South-south and North-central zones are more fragmented in terms of language as there are many languages spoken in the zones. In the South-south, only three states: Delta, Rivers and Bayelsa out of the six states speak Ijaw. 
The two states have higher populations than other states. Other languages such as Ika, Igarra, Bini, Esan, Efik Ibibio, Annang, Eket, Oron, Ibibio and Kalabari are spoken in Edo, Akwa Ibom and Cross River states. For Northcentral, four states including the federal capital territory: Plateau, Niger, Kwara, Nassarawa and Abuja have Hausa as the prevailing language especially in major cities in addition to Gbagyi, Gwandara, Yoruba, Nupe, Eggon, Nupe, and Berom. The Hausa language is spoken seldom, if at all, in Benue and Kogi where Tiv, Idoma, Igala and Ebira are the major languages. As earlier said, the position of the current paper is that it is easier to manage about six states to agree to adopt a popular language in their geo-political zone where there are similarities in culture than twisting the whole country to accept a particular language. The southwest states have Yoruba as the principal language while the southeast states have Igbo as the leading language.

In the light of the above and given the dominant language in each geo-political zone, the study proposes the adoption of four indigenous languages along the geopolitical zones as follows: Southeast (Igbo), Southwest (Yoruba), Northeast (Hausa) Northwest (Hausa), South-South (Ijaw) and Northcentral (Hausa). There is no doubt, that choosing a common language along geopolitical boundaries will save Nigeria the problem of managing too many indigenous languages given its heterogeneous nature. The choice of common languages along geopolitical boundaries may appear difficult in the short and medium-term but with continuous information and orientation, it is quite feasible in the long term. The people of each geographical zone will understand that the option is for geographical integration and cohesion, ease of communication, more participation in governance, relevance in teaching and learning, development of science and technology in the indigenous languages, and above all, a sense of common identity irrespective of tribal affiliations along geographical boundaries.

In addition to developing indigenous languages along the geopolitical axis, the English language should maintain its status as the official language of communication unifying the various geopolitical zones. The use of the English language as Nigerian's lingua franca may look like perpetuating colonialism or imperialism, but it is inevitable in uniting the various indigenous geographical languages and for global relevance. The English language has overriding influence in the world that 'countries with radical language policy like India and Tanzania have not been able to do without the English language' (Akindele and Adegbite, 1999, p. 99). The English language is the world's leading language and gateway to education, science, technology, commerce and international communication. It opens limitless opportunities for its users. Onuigbo and Eyisi (2007) citing Omodiaogbe (1997) express the obvious role of the English language in the unity of Nigeria.

Similarly, Okoh (2006, p.258) maintains that only the most ignorant, myopic and prejudiced people can attempt to deny that Nigeria enjoys a number of advantages by belonging to the world's English-speaking community With this language option, roles and recognition are assigned and accorded to both the exogenous and indigenous languages. The recognition of indigenous languages as a viable instrument for national development is also in line with the earlier recommendations of Banjo (1995), Emenanjo (1990) and Essien (1990). Such roles may include the use of the geographical indigenous languages in education, governance, science and technology, literature, religious activities, law courts, press, and other areas where the geographical language can be used. 


\section{Implication of the Proposed Option}

According to Elugbe (1990, p. 10), national languages may be languages that are chosen in terms of their 'geographic spread' and their location nationwide. There is no doubt that evolving common languages along this axis is easier to manage than bending the whole nation to accept one out of over 520 languages operational in the country which may denigrate into chaos. For instance, countries like India and Sri Lanka were thrown into a pandemonium where Hindu in India and Sinhalese in Sri Lanka attempted to evolve single common languages in their countries. It is arguable that choosing four common languages in a country like Nigeria may still breed ethnicism instead of nationalism, but the point remains that adopting common languages along geopolitical boundaries will enkindle more trust and consciousness for nationbuilding given the fact that the languages chosen are dominant in the zones.

In addition, the states apart from sharing common boundaries have similarities in terms of cultural, social and most times, religious affiliations. With the agreement, the choice of four dominant indigenous languages will propel development and integration in the zones. Inasmuch as there is a need for a common language in a country for national identity, a single common language option in a country is not a guarantee for 'nationism' or development. What is important is that a country has common language option(s) that work for them. It should be noted that countries like Rwanda, Burundi, and Somalia in Northern Arabs are monolingual countries; yet, are still underdeveloped in terms of per capita income and gross domestic product. On the contrary, countries like Belgium with three common languages operational in the nation: French, Dutch and German, and Switzerland with four common languages: German, French, Italian and Romansh are developed in terms of the standard of living measured by the gross domestic product and per capita income. In the case of Switzerland, the four languages are even represented on the Swiss banknote as a symbol of unity. This evidently shows that a single national language is not a necessary condition to forming a nation.

Other variables culminate in the development of a nation. Ofuokwu (1990, p.80) citing Williamson (1980) clears the air on the argument about a single common language bond when he writes that "a common language serves to cement unity only where there is already a will or at least, no opposition to such unity". Different languages in a nation especially when the languages are few should not create division. Division on grounds of language use in any nation is always an ideology created by the users of the languages in a nation to create disunity. What matters is the attitude of the people towards the chosen languages. Ndukwe (2015) citing Fishman (1968) points out that differences do not need to be divisive. He opines that divisiveness and unification are ideological positions that can either magnify minor differences or ignore major differences for the development of the nation. The four common languages if accepted will encourage more inclusion/participation in governance by the citizens than they have been excluded on the basis of barriers in language use. It will also foster unity, trust, reduce suspicion, sectionalism, tribalism, and engender national development. 


\section{CONCLUSION}

The paper examined national language and national development issues and establishes a relationship between language tendencies and national development. The paper holds that development is not sought only through a single common language in a nation, but can equally be sought through a few common languages in the nation. In a multi-linguistic/heterogeneous country like Nigeria, evolving a national language has become increasingly difficult and is seen as more of a political issue than a linguistic matter. The choice of a particular language from any ethnic group is seen as a way of conferring political dominance/superiority on the ethnic group. The present paper advocates the choice of a common language along geopolitical boundaries. A common geopolitical language will bind people of like tribes, religion, ethnic boundaries and cultural affiliations together in language. While geographical/geopolitical languages serve zonal purposes, the English language will continue to serve as the official language in the nation. From the analysis of Nigeria's population census and use of dominant languages in the geo-political zones, the implication is that in addition to English, Nigeria will have four common languages: Hausa, Igbo, Yoruba and Ijaw which are chosen based on their geographical spread.

\section{REFERENCES}

Akindele, F. \& Adegbite, W. (1999). The Sociology and politics of English in Nigeria.An introduction. Ife: Obafemi Awolowo University Press.

Akmajian, A., Demers, R., Farmer, A. \& Harnish R. (2001). Linguistics: An introduction to language and communication ( $5^{\text {th }} \mathrm{ed}$ ). New Delhi: Prentice-Hall of India.

Aziza, R. O. (1998). Nigerian languages and national development. In A. Oyewole (Ed.), Nigeria languages for national development. Ibadan: Longman Communication.

Banjo, A. (1995). On language and use and modernity in Nigeria. In K. Owolabi (Ed.), Language in Nigeria: Essays in honour of Ayo Bamgbose, (pp. 177-188). Ibadan: Group Publishers.

Chumbow, B.S. (1990). The place of the mother tongue in the policy of education. In E.N. Emenanjo(Ed.), Multilingualism, minority languages and language policy in Nigeria. (pp 61-72). Agbor: Central Books Limited.

Elugbe, B. O. (1990). National language and national development. In E.N. Emenanjo(Ed.), Multilingualism, minority languages and language policy in Nigeria. (pp 1019).Agbor: Central Books Limited.

Elugbe, B. (1995). Nigerian Pidgin: Problems and prospects. In A. Bamgbose, A. Banjo and Thomas (Eds.), New Englishes: West African perspective (pp. 284-299). Ibadan: Mosuro Publishers.

Elugbe, B. (2006). Documenting endangered Nigerian languages: challenges and constraints. In: Proceedings of the national workshop on best practices to safeguard endangered Nigerian languages.

Emenanjo, E.N. (1990). In the tradition of the majors: Lessons in language engineering for The minority languages. In E.N. Emenanjo(Ed.), Multilingualism, minority languages and language policy in Nigeria. ( pp 88-98). Agbor: Central Books Limited.

Essien, O. E. (1990). The future of minority languages. In E.N. Emenanjo(Ed.), Multilingualism, minority languages and language policy in Nigeria. ( pp 155-168). Agbor: Central Books Limited. 
Federal Republic of Nigeria. (2010). 2006 Population Distribution by sex, state, LGA and Senatorial Districts. National Population Commission, Abuja, Nigeria.

Fromkin, V., Rodman, R. \& Hyamas N. (2011). An introduction to the language. Canada: Wadsworth Cengage Learning.

Ike, J.N. (1998). Language and national development: The Nigerian Experience. Abuja: Wilbest Educational Books.

Jowitt, D. ( 1995). Nigeria's national language Question: Choices and constraints. In A. Bamgbose, A. Banjo \& A. Thomas( Eds.), New Englishes: West African perspective(pp. 34- 56). Ibadan: Mosuro Publishers.

Ndolo, I.S. (1989). The case for promoting the Nigerian Pidgin language. Journal of Modern African Studies. 27. (4), $679-684$.

Ndukwe, J.I.( 2015). S. The question of a national language in national development IOSR Journal of Humanities and Social Sciences. 20. (10), 75 -79.

Nwobia, N. U. (2015). The place of indigenous Nigerian languages in national development. semantic scholar.org/paper/the place-of- indigenous- Nigerian- languages- in Emeka Nwobia

Ofoegbu, C.O. (2017). Issues in language and national development. Onitsha: Mustard Printing and Publication Company.

Ofuokwu, D. (1990). Ethnolinguistic vitality and language planning: The Nigeria situation. In E.N. Emenanjo (Ed.), Multilingualism, minority languages and language policy in Nigeria. (pp73-80). Agbor: Central Books Limited.

Ogunmodimu, M.(2015). Language policy in Nigeria: Problems, prospects and perspectives. International Journal of Humanities and Social Sciences. 5(9), 154-160

Okoh, N. ( 2006). The challenges of Englishes in Nigeria. Port Harcourt: Pearl Publishers.

Olaoye, A.A. (2013). The role of indigenous languages in national development: A case study of Nigeria linguistic situation. International Journal of Applied Linguistics \& English Literature 2(3), 29-34.

Onuigbo, S. \& Eyisi J.(2009). English language in Nigeria: Issues and development. Calabar: Paclen Publishers.

Osuafor, C.C. ( 2002). The English language in Nigeria. Owerri: Great Versatile Publishers.

Oyetade S. (2003). Language planning in a multi-ethnic state: The majority/ minority dichotomy in Nigeria. Nordic Journal of African Studies 12(1): 105-117. 